\title{
Biogas Productivity as Renewable Energy and Performance of Waste Water Treatment in Tofu Small Scale Industry using an AnSBR Reactor
}

\author{
Suparni Setyowati Rahayu ${ }^{1 *}$, Totok Prasetyo ${ }^{1}$, Purwanto Purwanto ${ }^{2.3}$, Budiyono Budiyono ${ }^{2.3}$ \\ ${ }^{1}$ Mechanical Engineering Department, Politeknik Negeri Semarang, Semarang Indonesia \\ ${ }^{2}$ Doctoral Program of Environmental Science, School of Postgraduate Studies, Universitas Diponegoro, Semarang Indonesia \\ ${ }^{3}$ Department of Chemical Engineering, Faculty of Engineering, Universitas Diponegoro, Semarang Indonesia
}

\begin{abstract}
A research that analyzed the relationship between biogas production as renewable energy and performance of waste water treatment in tofu small industry using AnSBR reactor has been conducted. This research used system operation method in batches in to get a description of how the biogas production system works as it was operated in the batch mode, which is applied in tofu industry. An instrument capable of operation in batch mode using AnSBR reactor was designed as it does not require sludge re-circulation. An AnSBR reactor includes five stages of; filling, reaction, settling, decanting, and stabilization (idling state). The research was run for 24 days using biogas collected in a tank. Biogas was measured for each HRT starting on the second day HRT to $24^{\text {th }}$ day HRT. Biogas characteristics were monitored on day $16^{\text {th }}$ for contents of $\mathrm{CH}_{4}, \mathrm{CO}_{2}$ and heat value. Results show that $\mathrm{CH}_{4}$ content in the biogas amounts to $78.26 \%$, while $\mathrm{CO}_{2}$ comprises $20.16 \%$. Meanwhile, the heat value, which depends on acid methane and $\mathrm{CO}_{2}$ content, is $4,246.55 \mathrm{kkal} / \mathrm{kg}$.
\end{abstract}

\section{Introduction}

Application of science and technology for waste water treatment will minimize negative effects of this waste that environmental management can be carried out properly. In order to endorse environmentally friendly sustainable development, the science and technology of waste water treatment needs to be disseminated in the education community, within the general public, and also in business and industry, including the tofu industry.

Tofu waste water can be treated with anaerobic biological process to produce biogas as its inherent characteristic of high concentration biodegradable organic compounds of protein, adequate alkalinity, phosphor, nitrogen and micronutrients suitable for microorganism growth makes anaerobic process the most suitable for its treatment. High content of organic compound is a high energy source in the form of methane that will allow anaerobic bacteria to survive for a long time without the presence of food/substrates. These makes waste water treatment in small scale tofu industry a possibility [1].

An efficient bioreactor should have adequate biomass idling time and facilitate even mixing for contact between cells and their substrates to take place. AnSBR can meet this requirement. Microorganisms in an AnSBR reactor tend to be lifted and re-deposited due to the formation of gas in the process [2].

The most significant advantage of an AnSBR reactor is its ability to separate acid-genesis and methane-genesis longitudinally in its lower part. This facilitates proper growth conditions for different microorganism groups [3].
Other than that, constructing this type of reactor is simple and cheap. There are neither moving parts nor mechanical mixing that bacteria loss in the reactor is small and the outflow is relatively free of biomass solids. This is important as hydrodynamics and mixing level in the reactor affect contact between substrates and microorganisms, and hence influences mass control transfer and reactor performance [4].

It has been mentioned earlier that an AnSBR is simple and easy to construct as there is no need for moving parts or a mixing machine. The design itself helps separate acid-genesis and methane-genesis processes that significant advantages are already inherent. This reactor functions like a two phase system without the need for high cost and does not cause control issues [5].

The performance of an AnSBR reactor in separating COD is around $65-95 \%$ and maturation process has to be observed for the first 3 months. Overall, the advantages or an AnSBR reactor compared to any other system are; simple design, no moving parts, nor need for mechanical mixing, inexpensive, low risk of clogging, and low risk of sludge bed expansion, and low operational cost [6].

In terms of the biomass, solid retention time in this reactor is long without the need for media or precipitation room. It takes some time to form mud and resulting mud itself is also only a little. This mud lasts for quite a while that frequent dumping is not necessary, and this reactor does not require microorganisms with certain precipitation abilities [7].

AnSBR is a bioreactor that is both simple and easy to operate with little organic and shock loading hydraulics

Corresponding author: suparnirahayu@yahoo.co.id 
only slightly affect processing efficiency. Considering the benefits of this type of reactor, its use for tofu waste water treatment should be endorsed [8].

The disadvantages of this reactor, as reported by some researchers, include sensitivities to high load anaerobic processing. The other drawbacks, as is the case with the other biological processing, are the need for long Hydraulic Retention Time (HRT), meaning high reactor volume, high concentration of biomass, and the need for biomass wash-out control off the reactor. Therefore, research on anaerobic tofu waste water treatment has to deal with finding the most effective way of holding anaerobic microorganism in the reactor [9].

Tofu waste water treatment in an AnSBR reactor makes use of sewage mud. This mud serves as biological suspension or active microbe mass that degrades dissolved organic materials. This technique takes advantage of microbes that degrade complex organic compounds into stable substances, and hence reduces waste COD down to around $70-95 \%$ [10].

Sewage mud can also metabolize and breakdown pollution materials contained in waste water. This mud is an undissolved material; it typically consists of organic fibers rich in celluloses and living microorganisms. Therefore, there is also an interest in figuring out the most effective mud composition for treating tofu waste water, to allow using the mud as active mud [11].

Sewage mud consists of microorganisms in adequate amount to also serve as microorganism germ or oxidation agent in biological treatment of waste. Mud to be used as microorganism germ only comes from sewage of the tofu industry. Hence, development of biomass into active mud cannot be separated from the environment of biomass source. On the other hand, microorganisms coming from polluted waters are usually of high organic content of heterotopic organisms [12].

Adequate supply of food is also needed for microbes to proliferate. This agrees with an earlier research stating that longer germination results in higher microbe load as microbes split and multiply in numbers. Microbes need some time to proliferate, but when required components are available they can multiply fast and hence, does more oxidation on organic compound in tofu waste water. Therefore, the use of sewage mud has great potential to reduce the amount of pollutant in tofu industry [13].

The process in an AnSBR reactor can be categorized as reaction-suspended growth and separation in a single tank. The critical aspect of this process is sludge precipitation rate during precipitation period prior to effluent decanting [14].

\section{Method}

The waste water used in this research is small scale tofu industry waste. Sample was taken during the working hours from sewage inlet, as these working hours produces maximum quantities of waste water and in terms of quantity, the organic content is highest.

Collected waste water was then added with $\mathrm{CaCO} 3$ to raise its $\mathrm{pH}$ to an optimum $\mathrm{pH}$ level to facilitate anaerobic processes. $\mathrm{CaCO} 3$ addition took into account neutralization calculation that will result in $\mathrm{pH}$ reaching 7 , which is in the rage of optimum $\mathrm{pH}$ level of 6.8-7.4.

This stage of research was aimed at understanding the effect of Hydraulic Retention Time (HRT) on the performance of AnSBR bio digester operated in batch mode for biogas production.

Batch mode was chosen in order to get proper description of biogas production system performance, because batch mode is actually operated in tofu making. The research started with designing an instrument capable of operating in batch mode. Some considerations for this design include: (1) AnSBR digester allows solids to be either suspended and floating that it allows effective contact between substrates and microbes; (2) the system comes with an automatic temperature control to ensure control operation at optimum temperature; (3) it is also equipped with a biogas pressure gauge to monitor biogas pressure to prevent damage to the instrument at certain pressure levels; (4) the system also has a microbe inoculum from the sewage. This is one specific factor for biogas production from tofu waste water, the other specific factor being microbe concentration in the digester.

COD and TSS analyses were carried out for each time interval of AnSBR bio digester operation. Analysis for gas composition was conducted at the end of AnSBR bio digester operation period. The effects of sewage mud, COD, TSS were then observed for maximum performance. Optimum conditions for factors of inoculum, HRT and TSS will be optimized and further enhanced for the long terms use of this system.

\section{Result and Discussion}

When the system was running, TSS concentration was also measured to find out the effect of HRT on effluent quality, based on TSS output concentration during system running.

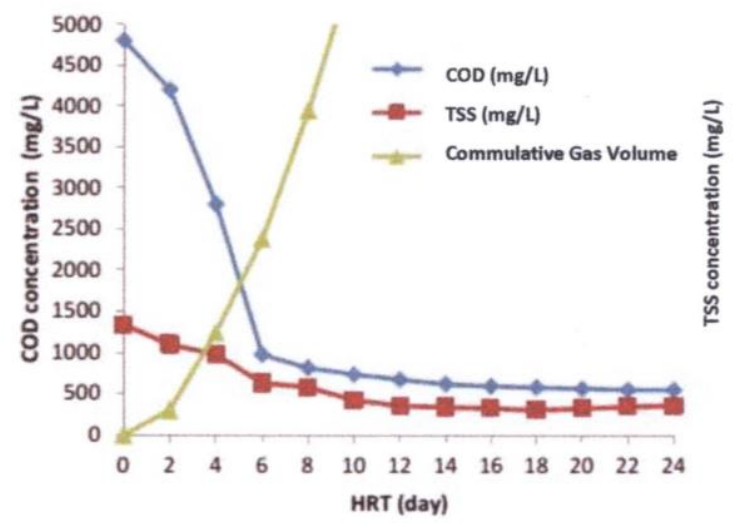

Fig. 1. Decreasing of TSS and COD concentration during system running.

Decreasing TSS concentration measured in each HRT effluent comes along with less COD concentration. This is evident in Figure 1, in which decreasing TSS concentration is in line with lowering COD. Except for the 20th day to the 24th day, TSS concentration is rising.

This increasing TSS is due to the fact that some bacteria were already in dying phase. This dying phase is 
also marked with COD concentration that is relatively constant. Constant COD concentration on day 20 to day 24 is caused by less substrate available that comes with dead bacteria.

Figure 1 and some earlier analyses show that optimum HRT in TSS separation was obtained on day 16. TSS concentration on the 16th day is still above the standard limit set by Regional Regulation of Central Java Province No. 5 year 2012. Nonetheless, physical conditions have been improved as can be seen with lower TSS concentration in effluent.

System running carried out for 24 days produced biogas stored in a tank. Biogas was measured on each HRT started from HRT 2, onwards to HRT 24. On the 10th day, $5815 \mathrm{~mL}$ of biogas was obtained, and it kept on increasing right to HRT 24. This is a significant increase. On day 14, biogas production reached its maximum. And on day 16 onwards, biogas production lowered. Even though day 16 resulted in a biogas volume of $11225 \mathrm{~m}$, biogas production kept on decreasing right to HRT 24 . Nonetheless, cumulative volume of biogas production seems to be constant. Biogas production on day 22 to day 24 still lowered, but cumulatively, it has always looked constant since day 16 . Therefore, day 16 was an optimum production time.

Constant biogas volume shows that most of the acid substrates have been converted to produce methane. Hence, the phase of optimum HRT has passed. This is in line with Metcalf \& Eddy (2003) who stated that $72 \%$ of biogas produced comes from substrates, while the remaining figure is from $\mathrm{CO} 2$ and $\mathrm{H} 2$ substrates.

During system running, characteristic testing for biogas produced up to day 16 include contents of $\mathrm{CH} 4$, $\mathrm{CO} 2$ and biogas heat value. Examinations show that $\mathrm{CH} 4$ content in the biogas amounts to $78.26 \%$, whereas $\mathrm{CO} 2$ content reaches $20.16 \%$.

Biogas heat value after examination is 4,246.55 $\mathrm{kkal} / \mathrm{kg}$. This value depends on the amount of methane acid and $\mathrm{CO} 2$ in it. The more the methane content, the higher the heat value is.

\section{Conclusion}

Some variables that affect the process of biogas production as renewable energy includes $20 \%$ sewage mud. The maximum condition for biogas production in an AnSBR bio digester is reached on day 16, with COD concentration of $87.51 \%$ and TSS concentration of $75.37 \%$.

Biogas produced on HRT 16 contains $78.26 \% \mathrm{CH} 4$ and $20.16 \% \mathrm{CO} 2$ and are produced with an AnSBR bio digester operating in batch mode involving states of filling, reaction, precipitation, decanting, and stabilization. Meanwhile, biogas production using conventional bio digester only yields biogas composed of $72.16 \% \mathrm{CH} 4$ and $18.12 \% \mathrm{CO} 2$.

The researcher wishes to thank DRPM RISTEKDIKTI for the funding of this research, State Polytechnic of Semarang and Diponegoro University for facilitating this cooperative research.

\section{References}

1. Alphenaar, P. A., A. Visser, and G. Lettinga Biosource Technology, 43, 249 (2013)

2. Azimi, A. A. and Zamanzadeh, M, Int. J. Environ. Sci. Tech. I, 1, 51-57, Spring (2014)

3. Carucci,G.,F.Carrasco,K.Trifoni,M.Majone, and M.Beccari,. J.Environ. Eng. 131 ,7, 1037-1045 (2015)

4. Demirer,G.N.and S.Chen, Journal of Chemical Technology and Biotechnology, 79, 1381-1387 (2014)

5. El-Sheikh, Mahmoud A., Hazem I. Saleh, Joeseph R. Flora, Mahmoud R. AbdEl-Ghany. Desalination 276, $253-259$ (2011)

6. George Nakla, Andre Lugowski, Jounika Patel, Bioresource Technology, 97, 1, 1-14 (2011)

7. Hang-Qing Yu, Zhen Hu. Hu, Tan - Qiu Hong, Guo - Wei Gu, Bio. Chemistry 38, 507 - 513 (2008)

8. Pakarinen, 0., A. Lehtomaki, S.Rissanen, J. Rintala, Bioresour. Technol. 99, 15, 7074-7082 (2013)

9. Pozo, R.D., V. Diez, S. Beltran, Bioresour. Technol. 71, 2, 143-149 (2015)

10. Rajeshwari, K.V., M. Balakrishnan, A. Kansal, K. Lata, V.V.N. Kishore, Renewable and Sustainable Energy Reviews, 4, 2, 135-156 (2013)

11. Sarapatka, B, Biomass and Bioenergy, 5, 5, 387-393 (2013)

12. Van Haandel, A,. Rev. Environ. Sci. Bio Technol, 521 (2011)

13. Vavilin,V.A.andI.Angelidaki, Biotechnology and Bioengineering 89 ,1, 113-122 (2015)

14. Yasar, Abdullah dan Tabinda, Amtul Bari,. Polish J. of Environmental Study, 19, 5 (2010) 